\title{
ATTRACTIVENESS OF MUNICIPALITIES FOR THE POPULATION IN 2010-2016
}

\author{
Patsiorkovskiy Valeriy V. \\ Professor, D.Sc. (Econ), Chief Scientific Officer, \\ Institute for Socio-Economic Studies of the Population RAS. \\ Address: 32, Nakhimovskiy Av., 117218, \\ Moscow, Russian Federation. \\ E-mail: patsv@mail.ru
}

\begin{abstract}
The work examines the main trend in changes to Local Self-Government in recent years. During this time, changes in municipal government were aimed at reducing the total number of municipal formations and outstripping the growth in the number of city districts. This growth is realized in three ways. From 2010 to 2016 only 509 out of 2328 municipal formations $(21.9 \%)$ increased in population, by $5.7 \%$. The remaining $78.1 \%$ of municipal formations experienced a loss in population. There are 220 city districts and 289 municipal districts among those municipal formations which with a population growth in 2010-2016. These municipalities are presented below.

The main hypothesis of population growth in some municipalities and its decline in others is based on the uneven distribution of central places in the settlement system that ensure the availability of goods and services for the entire population that gravitates towards them. This circumstance is due to the fact that the municipal system in Russia inherits all the features of the pre-existing administrative-territorial division. Therefore, it weakly meets the requirements of the location of production, meeting the needs of the population in goods and services, as well as the whole complex of market relations. The basis for calculations is the "Municipal Russia" database.
\end{abstract}

Keywords: local self-government; municipal formations; two levels of municipal formations, city districts; municipal districts; urban settlement; rural settlement; the population.

Citation: Patsiorkovskiy, V.V. (2017). Attractiveness of Municipalities for the Population in 2010-2016. Public Administration Issues, Special Issue (electronic edition), pp. 60-71 (in English); doi: 10.17323/1999-5431-2017-0-5-60-71.

M unicipalities are the ultimate agents of spatial development and the entire regional economy as a whole. The population, households, production, engineering and social infrastructure are located on their territory. Both economic growth and demographic development are taken into account in the assessment of the regional economy. 
Therefore the attractiveness of a particular municipality for the population can serve as a good indicator of affairs at the local level.

The current system of Local Self-Government was formed by the time the last census of the population was conducted in 2010. There are two levels of municipal formations. The first level is a city district (gorodskoy okrug) and municipal district (munitsipal'nyii raion). The second leve is urban and rural settlements (gorodskie i selskie poselenia) ${ }^{1}$.

This article considers movement of the population only in the municipalities of the first level.

According to the last census, there were 2,341 municipalities of the first level in 2010 including 516 city districts and 1825 municipal districts ${ }^{2}$. As a result of various transformations there were 552 city districts and 1776 municipal districts by the beginning of 2016. The total number of such municipal formations was reduced to 2328 . These changes led to the number of municipal urban and rural settlements at the settlement level decreasing by 1091 units.

We can say that in 2010-2016 changes in municipal government were aimed at reducing the total number of municipal formations and outstripping the growth in the number of city districts. This growth is realized in three ways, namely by combining municipal districts and city districts or by dividing municipal formations into municipal districts and city districts, or by changing the status of an urban settlement in connection with giving it the status of city districts. The transformation of municipal formations is carried out by the laws of the subjects (regional authorities) of the Russian Federation.

The leader of such transformations is Magadan region. All of the areas here are converted into city districts. There is still one municipal district plus 18 newly formed units of city districts in Sakhalin region. Five municipal districts and 68 units of city districts were created in the Sverdlovsk region. It should be noted that in the past three years similar transformations have been gaining increasing strength in the Moscow region. There were 29 municipal districts and 39 city districts there by the beginning of this year.

In contrast, the Republic of Bashkortostan has 54 municipal districts and 9 city districts. The Republic of Tatarstan has 43 municipal districts and 2 city districts. The Altai krai has 59 municipal districts and 10 city districts. The Krasnodar krai has 37 municipal districts and 7 city districts ${ }^{3}$. As we can see, the prevalence of municipal districts in the territorial structure of the regions remains.

From 2010 to 2016 only 509 out of 2328 municipal formations (21.9\%) increased in population, by $5.7 \%$. The remaining $78.1 \%$ of municipal formations reduced in population, the population movement in this category is not considered futher in this study.

\footnotetext{
1 State Duma of the Russian Federation. Federal Law N131-FZ of October 6, 2003. On General Principles of the Organization of Local Self-Government in the Russian Federation. Available at: http://www.consultant.ru/ document/cons_doc_LAW_148889/(accessed: 25 March, 2017).

2 All-Russia Population Census of 2010. Volume 1. Population size and accommodation. - M: FSGS, 2012, p. 310 .

${ }^{3}$ Database "The Municipal Russia". Authors and rights holders: Patsiorkovskiy V.V., Kolennikova O.A., Simagin Yu.A. Number of state registration: RU 2014620760 of 27.05.2014.
} 
Of course, the 509 municipal formations are incomparably greater in number and better for the territorial organization of the country than a dozen agglomerations. "We must create in the territory of Russia, maybe 10-15 metropolitan cities, which will be comparable in the East with Asian cities, in Europe - with western cities," said A. Kudrin ${ }^{4}$. Similar thoughts were expressed by the current head of the Bank of Russia even earlier 5 .

The problem is that no one knows whether this is too much, too little or just enough to increase the coherence of the country's territory, and its spatial and socio-economic development. Therefore the study of the movement of the population in such municipal formations is very important. We need to know their placement and their coverage as a supporting framework for resettlement and the entire inhabited territory of the country.

Among the municipal formations which attracted people in 2010-2016, were 220 city districts and 289 municipal districts. The latter circumstance can be regarded as a known benefit. After all, municipal districts provide an assortment of small towns and rural areas, as well as the location of the rural population. At the same time it is testament to the flaws in the proposals on population concentration in several megacities.

Such proposals are based on considerations of economic development and increased economic growth. "We, at the expense of the concentration of the population, get those effects that give high labor productivity, added value, GDP growth and create a different quality of life", ${ }^{6}$ wrote Director General of the Institute "Giprogor".

Meanwhile, under modern conditions, the balanced and sustainable functioning of populated areas and settlement systems can hardly be achieved along the path to realizing the territorial strategy of exclusively economic development. Such approaches are based on outdated scientific assumptions related to the separation of a person from his natural origin and a limited understanding of the trends taking place. What they have brought is well known.

In particular for our country today all transforming activities should be minimized without a solution to the tasks associated with the expanded reproduction of the population and the consequences of the formation of a new technological structure. The advantages and disadvantages of the main categories of populated areas (large, medium, small towns and rural settlements) are meaningful only with respect to the whole that makes up the rural-urban continuum (the settlement system).

The rural-urban continuum has developed in a natural, historical way for a long period of time (Patsiorkovskiy, 2010). It is hardly right to destroy it cor-

\footnotetext{
${ }^{4}$ Kudrin vypisal Rossii retsept ozdorovlenia cherez megapolisy [Kudrin has written to Russia the recipe for recovery through megacities]. Available at: https://utro.ru/articles/2017/01/15/1312332.shtml (accessed: 20 March, 2017).

5 Nabiullina: RF nuzhny proekty modernizatsii dla 12 gorodov-millionnikov [RF is needed for modernization projects for 12 megacities]. Available at: http://news.mail.ru/politics/7546478/ (accessed: 20 April, 2017).

${ }^{6}$ Agglomeration - the general plan of the disintegration of Russia? Available at: https://regnum.ru/news/ polit/2210111.html (accessed: 20 March, 2017).
} 
rectly from considerations of efficiency, the location of productive forces, economic functions and even a very important geopolitical significance.

It is a mistake to correct the settlement system from the traditionally narrow positions of rational distribution of production and economic functions. Moreover, these must be expanded to take into account the role of various components of the settlement system in the reproduction of the population. Under conditions of a low birth rate, it is impossible to pursue a socio-economic policy aimed at concentrating the population in large cities. The effectiveness of such measures from the standpoint of economic growth is very doubtful. There are lot of risks associated with the depopulation and destruction of the settlement system.

Population reproduction is primarily associated with rural areas and small towns, while large cities by definition are long way from solving this problem. This fact has long been fixed in science and practice. "The inability of the urban population to their own reproduction is a biological consequence of a combination of factors contained in a complex of urban life, and the decline in fertility in general can be considered one of the most important signs of urbanization in the Western world" (Wirth, 2005). However this could not be taken into account until the reproduction of the population was extended. People were viewed as an unlimited resource of labor and for various kinds of mobilization initiatives.

Today, after several years of tremendous efforts aimed at demographic development in our country, the total fertility rate in the city is 1.6 children (per woman of fertile age) while in the village it is 2.3 children $^{7}$. For a better understanding of this it is appropriate to bear in mind that these figures indicate that the village has already approached the expanded reproduction of the population, while in the city the birth rate is still significantly lower than the level of replacement of generations. Unfortunately, three quarters of the population live in the city just now. This circumstance serves as a severe limitation of the prospects for solving demographic problems.

An analysis of population reproduction at the micro level shows that in the territorial context there are a significant number of family households in our country that can be considered as growth points for achieving the goals of demographic development. The key words here are large families, rural areas and small towns. In other words, we need to keep in mind the municipal districts. Under the appropriate demographic policy, such growth points could be the Republics of Bashkortostan, Dagestan, Chechnya, Tyva, Chuvashia, Altai, Krasnodar, Stavropol krai, Orenburg and Tambov regions.

All the municipal formations, which increased in population, were distributed according to the Federal Districts as follows (Table 1).

From the data given in this table, it can be seen that only the Central, Volga and Siberian Federal Districts retain the similarities of city and municipal districts

\footnotetext{
7 Demographicheskii Yezhegodnik 2015. Moscow: FSGS, 2015. Available at: http://www.gks.ru/bgd/regl/ B15_16/Main.htm (accessed: 20 March, 2017).
} 
in their scale. For other Federal Districts the city districts dominate in the NorthWest, Ural and Far East while in the South and North-Caucasian Federal Districts municipal districts prevail.

Table 1

\section{Distribution of municipalities with a growing population in 2010-2016 by Federal Districts}

\begin{tabular}{|c|c|c|c|c|}
\hline \multicolumn{2}{|c|}{ Municipal Districts } & \multicolumn{2}{|c|}{ City districts } & Federal Districts \\
\hline$\%$ & Number (unity) & $\%$ & Number (unity) & Central \\
\hline 19,0 & 55 & 22,2 & 49 & North-West \\
\hline 5,9 & 17 & 11,3 & 25 & South \\
\hline 12,5 & 36 & 6,3 & 14 & North-Caucasian \\
\hline 21,5 & 62 & 9,5 & 21 & Povolzhsky (Volga) \\
\hline 16,3 & 47 & 14,9 & 33 & Ural \\
\hline 6,2 & 18 & 16,7 & 37 & Siberian \\
\hline 16,3 & 47 & 13,1 & 28 & Far East \\
\hline 2,4 & 7 & 5,9 & 13 & Total \\
\hline 100,0 & 289 & 100,0 & 220 & \\
\hline
\end{tabular}

Source: Database "The Municipal Russia”. Authors and rights holders: Patsiorkovskiy V.V., Kolennikova O.A., Simagin Yu.A. Number of state registration: RU 2014620760 of 27.05.2014.

Given the high proportion of the Central and Volga Federal Districts in the structure of the municipal formations with a growing population, we can confidently talk about the attractiveness of these regions for the urban and rural population. Having minimum attractiveness is typical for the Far East Federal District. There are only isolated cases of municipal formations that retain attractiveness for the population in that area.

Proceeding from the fact, that many cities form the support frame of the settlement system, further attention will be paid to the consideration of changes in the population of the city districts. It is preliminarily appropriate to note that in contrast to many municipal districts, low fertility is characteristic of all city districts. Population growth in city districts is possible due to migration mobility. All city districts grew up with the population divided into three groups: attracted up to one percent of the population, attracted from one to $5.7 \%$ (the national average) and attracted more than $5.7 \%$ of the population. Their distribution by Federal Districts is shown in Table 2.

The data Table 2 allows us to see the peculiarities of the attractiveness of various groups of city districts in the Federal Districts. For example, in the city districts group with a minimum population growth there are 30 city districts with slightly more than half of these concentrated in the Central and Volga Federal Districts. 
Table 2

\section{The distribution of the three groups of city districts with the growing population in 2010-2016 by the Federal Districts}

\begin{tabular}{|c|c|c|c|c|}
\hline \multicolumn{4}{|c|}{ The three groups of city districts } & \multirow{2}{*}{ FD } \\
\hline Total & The largest increase & Average Increase & Minimal increase & \\
\hline 49 & 23 & 18 & 8 & Central \\
\hline 25 & 10 & 12 & 3 & North-West \\
\hline 14 & 7 & 3 & 4 & South \\
\hline 21 & 9 & 11 & 1 & North-Caucasian \\
\hline 33 & 5 & 20 & 8 & Povolzhsky (Volga) \\
\hline 37 & 15 & 18 & 4 & Ural \\
\hline 27 & 13 & 13 & 1 & Siberian \\
\hline 13 & 10 & 2 & 1 & Far East \\
\hline 220 & 94 & 97 & 30 & Total \\
\hline
\end{tabular}

Source: Database “The Municipal Russia”. Authors and rights holders: Patsiorkovskiy V.V., Kolennikova O.A., Simagin Yu.A. Number of state registration: RU 2014620760 of 27.05.2014.

There are 97 city districts which had an average population growth. These were distributed almost uniformly around the Federal Districts, except for the South and Far East Federal Districts. In the group which showed the highest population growth there are 94 city districts. Their distribution has a certain slant to prevail in favor of the Central District and a shortage in the Volga and Southern Federal Districts.

In the Far East, North-Caucasian and Siberian Federal Districts only one city districts from each had a minimal population growth. Accordingly they were: Petropavlovsk-Kamchatsky (Kamchatka krai), Lermontov (Stavropol krai) and Novokuznetsk (Kemerovo region). In economic geography terms, these are three completely different cities.

Petropavlovsk-Kamchatsky is a large city. This is a regional center in an extremely remote and poorly urbanized area. It pulls the population from its surrounding territory. In 2010-2016 all other municipal formations of the Kamchatka krai lost some of their population (with the exception of those located on faraway islands in the Bering Sea - the Aleutian municipal district). Even the Elizovskiy municipal district lost some of its population. This contradicts the tendency for population growth in the suburbs of large cities.

This increase in the population is realized at the expense of regional migration. With its help, the population concentrates in the regional center. The limits of growth in this case are determined by the population of the region. For the Kamchatka krai it is noted that this circumstance has an important significance.

In contrast, Lermontov is a small city in the resort zone of the Caucasian mineral waters. It is close to a number of other more developed cities. In this group of city districts only Zheleznovodsk barely appreciably lost some popula- 
tion in the observed period. At the same time, Essentuki, Kislovodsk and Pyatigorsk showed significant attractiveness. Moreover, a similar attractiveness was shown by the Predgorny municipal district surrounding these cities. Such a population growth is realized due to interregional migration. It serves as a good indicator of the formation of an agglomeration in a given area.

The main problem associated with agglomerations in Russia is as follows: "Conurbations exist de facto as a natural stage of urban growth but they are not de jure as legal entities recognized by law. Hence all the problems: several interconnected settlements long existing as a single organism are constantly stuck in legislation, in which there is no concept of agglomeration"s. Therefore the problem here is not the gathering of the entire population in the agglomerations. It is necessary to promote their formation where they have already appeared, as well as to appear where there is an urgent need for them.

Finally, Novokuznetsk is a large industrial center in one of the most highly urbanized areas of the country. All the nearest city districts (Belovo, Osinniki, Prokopyevsk, etc.) as well as the Novokuznetsk municipal district lost some of their population during the observed period. Taking into account the fact that Novokuznetsk is a multidisciplinary center, there is more reasun to understand migration of the population in that area.

In addition, Novokuznetsk is the center of one of the largest agglomerations. Therefore it is hardly correct to believe that its growth has an attributing character. Here this territory with population of more than one million people is involved in economic circulation ${ }^{9}$. Increasing the connectivity in it can contribute to the socio-economic development of a huge region.

The three examples discussed above show that in recent years a similar trend of low yet still attractive for the population. Higher attractiveness has at its source two reasons. One of these is caused by the previously mentioned administrative-territorial transformations. Examples of such an increase exceeding as a rule $20 \%$ of the initial population size are the city districts of Balashikha (Moscow region), Anapa (Krasnodar krai), Magas (Republic of Ingushetia), and Koltsovo (Novosibirsk region). During the observed period such transformations were absent in the Far East, Volga and Ural Federal Districts. Basically they were implemented in these regions until 2010. In this text there is no possibility to dwell on their description.

As a moderate attraction based on certain internal reasons it is possible to give examples of the following city districts: Belgorod (Belgorod region), Pskov (Pskov region), Kaspiisk (Republic of Dagestan), Yoshkar-Ola (Republic of Mari El), Nizhnevartovsk (Khanty-Mansi Autonomous District-Yugra), Abakan (Republic of Khakassia), and Artem (Primorsky krai). In this case we deliberately took one city district in each Federal District and excluded the very large cities (with more than one million inhabitants). All of the largest cities, with the

\footnotetext{
8 Aliev, Sh. Kaspiiskii megapolis. Available at: http://kavpolit.com/articles/kaspijskij_megapolis-6126/ (accessed: 22 April, 2017).

9 Aglomeratsii Rossii. Available at: https://ru.wikipedia.org/wiki/Aglomeratsii_Rossii (accessed: 29 April, 2017).
} 
exception of Volgograd, increased in population in the period under review. Incidentally, their place in the settlement system and the significance to the socioeconomic development of the country are well described in literature and hardly need additional comments.

Belgorod, during the observed period, increased in population by $8.6 \%$. Moreover the Belgorod municipal district population rose by $6.9 \%$. In addition, the neighboring (in the direction of Starooskolsky city district) Korchansky municipal district displayed a similar population growth trend. The urban and rural populations grew in both municipal districts. It is quite possible that this circumstance indicates that the Belgorod and Starooskol'sko-Gubkin agglomerations tend to form a three-nuclear conurbation. This can reliably link the entire region and become a very significant component of the population's enormous territory.

In Belgorod it is believed that: "The development of the agglomeration should not proceed from the goal of growing the urban area by uniting the regional lands in a single municipal formation. The real meaning of the agglomeration is to create a stable economic development zone, comfortable conditions for citizens' living, the formation of business and attracting investments. Thus, it is planned to develop the Belgorod agglomeration not on the basis of absorbing a new space but by improving the transport infrastructure" (Morozova, 2014).

This development vector has a huge conserved resource at the moment. It is connected with the events in Ukraine. On the one hand, attempts to destroy the historically established connectivity of the Belgorod and Kharkov agglomerations could lead to a huge flow of population. On the other hand, the successful cessation of the crisis in the neighboring country and a return to traditional economic ties would strengthen the tendency for an even more powerful and attractive conurbation in the region.

In the North-West Federal District many city districts representing regional and republican centers showed an increase in population during the observed period. Notable among these are: Arkhangelsk, Kaliningrad, Novgorod, Petrozavodsk, Pskov, Syktyvkar and Vologda. Along with these regional centers, some the cities of regional subordination have also increased in population (Cherepovets, Kostomuksha, Kotlas, Mirniy, Zelenograd, etc.).

For example, the city district Pskov increased its population by $2.4 \%$. This is in a region in which the population decline was one of the first in the country to begin many years ago. The situation here is very similar to the situation in the Kamchatka krai, which has already been described. The difference is that the Pskov city district of the Pskov municipal district has increased its population. All the other municipal formations of the region lost some population in the observed period. In other words, here the population is concentrated in the center and its suburbs.

This means that there is a growing trend in individual housing construction and life on the land in the manor household. Of course, this trend alone cannot reverse the demographic crisis that has engulfed the region. At the same time it can be attractive for migrants from other regions of the country. Unfortunately 
the Pskov city district as well as its regional partner, the Great Lukie city district, are far too weak and lagging behind in their development to start the formation of an agglomeration that could determine the integrity of and offer positive changes to the whole region.

In the main part of the regions of the South Federal District only one or two city districts had any population growth in the observed period. In contrast, the largest increase was in the number of city districts in Krasnodar krai (Anapa, Armavir, Gelendzhik, Goryachy Klyuch, Krasnodar, Novorossiysk, and Sochi). The unconditional leaders in terms of enhancing their role in the settlement system and population are Krasnodar and Sochi. It is quite clear that in the near future the regional center will gain a million inhabitants. Thanks to the modernization of the transport infrastructure. Sochi will complete the formation of an agglomeration that pulls in all the settlements of the Black Sea coast from Adler to Tuapse.

In the North Caucasus Federal District, 9 city districts in the Republic of Dagestan increased in population in 2010-2016. Among them it is appropriate to note the following city districts: Buinaksk, Dagestan Ogni, Derbent, Izberbash, Kaspiisk, Kizilyurt. Makhachkala, Khasavyurt and Yuzhno-Sukhokumsk.

Makhachkala's city district, during the observed period, increased in population by $2.8 \%$. This city district continues to be the undisputed leader in settling the rapidly growing population of the republic and forming the Makhachkala-Kaspiiskaia agglomeration. "For Makhachkala this is now a vital necessity. The city actually merged with nearby settlements and without a single management of this large territory the capital of Dagestan can finally plunge into chaos"10.

In almost every region of the Volga Federal District, two or three city districts increased in population in the observed period. This includes all of the regional capitals. Five of them are the large cities-millionaires. Therefore it can be hardly any surprises outside of the established settlement system. Competing with Kazan, Nizhny Novgorod, Perm, Samara and Ufa is difficult today and will continue to be in the near future.

It should be noted that under certain circumstances the Saratov city district may enter the club of millionaires. Saratov "together with Engels and other settlements forms an agglomeration of 1.15-1.2 million people. There are proposals to unite Saratov and Engels in a single millionaire city" ${ }^{11}$. Other regional centers such as Cheboksary, Izhevsk, Kirov, Orenburg, Penza, Saransk, Ulyanovsk and Yoshkar-Ola will continue their development.

The Urals Federal District has already established a settlement support skeleton. Chelyabinsk, Kurgan, Tyumen, and Yekaterinburg are supported by the second echelon of large cities (Magnitogorsk, Nizhny Tagil, Nizhnevartovsk, Surgut, etc.). Many of these cities are centers of already formed (Ekaterinburg, Chelyabinsk) and currently forming Magnitogorsk, and Nizhny Tagil agglomerations.

\footnotetext{
${ }^{10}$ Aliev, Sh. Kaspijskij megapolis. Available at: http://kavpolit.com/articles/kaspijskij_megapolis-6126/ (accessed: 22 April, 2017).

11 Saratov. Available at: https://ru.wikipedia.org/wiki/Saratov (accessed: 23 April, 2017).
} 
Many city districts in the Chelyabinsk, Sverdlovsk and Tyumen regions have increased their population. In this regard the absolute leader is the Sverdlovsk region. It has 14 city districts (Aramil, Berezovsky, Yekaterinburg, etc.) which have increased in population. The peculiarity of such a rapid increase in some city districts of Sverdlovsk region is that almost all of them are satellite cities of Yekaterinburg. In fact, these processes testify to the development and growth of the attractiveness of all of the Ekaterinburg agglomeration. It is pertinent to draw attention to the fact that more than 50 city districts of the Sverdlovsk region were losing population during this period. All of them were outside of the Yekaterinburg agglomeration.

During the period under review, the tendency towards population concentration in regional centers prevailed in the Siberian Federal District. It most consistently manifested itself in the Republic of Buryatia, Irkutsk, Omsk and Tomsk regions. In them only regional centers increased their population.

In other regions, in addition to regional centers, the population more often increased only in one more city district, as was the case in the Republic of Altai (city district Kosh-Agachsky), the Republic of Tyva (city district AK-Dovurak), the Republic of Khakassia (city district Chernogorsk), the Trans-Baikal krai (city district Aginskoye), and Kemerovo region (city district Novokuznetsk). And in only three regions, namely the Altai, Krasnoyarsk krai and the Novosibirsk region, 4-5 city districts showed the tendency of population growth (city district Berdsk, Belokurikha, Norilsk, etc.).

In recent years Krasnoyarsk is the third city in Siberia to become a millionaire city. This circumstance as noted above indicates a slow but positive movement to strengthen the settlement system in the Siberian Federal District.

The state of affairs in the Republic of Buryatia and the Trans-Baikal Krai is rather complicated. Once in the Siberian Federal District they lost the right to any support associated with the development of the Far East. Today and even more so for the future, the mastery of this vast territory along the narrow strip of the Trans-Siberian Railway creates a lot of problems in regards to socio-economic movement to the Far East.

In 2010-2016, the same trend prevailed in the Far East Federal District. The population tended toward regional centers. Outside of other regional centers in this vast territory, only six city districts showed an increase in population. To this group belong the city districts Artem and Ussuriisk (Primorsky krai), Uglegorsk (Amur region), Anivsky, South Kuril (Sakhalin region), and Pevek (Chukotka Autonomous district). The attractiveness of the above mentioned city districts for the population is extremely important.

The problem is that there are very few of them offering some sort of habitable appearance to this distant extremity of our country. This remark is even more justified with regard to the problematic successes of the zones of advanced development formed in this Federal District. All of them ultimately imply the use of skilled labor and favorable living conditions for the population.

It seems that at the moment the "Far Eastern hectare" is the most interesting undertaking for the development of this territory. In any case, the availability of land for an individual homestead dwelling should be provided for 
a wide range of reproducibly capable and economically active family households throughout the domain of any settlement. Today it is possible just in one chosen region.

Therefore we can only welcome the consideration of the draft law that began in the State Duma providing for the granting, free of charge, to all desiring Russians, of land plots of up to 25 acers, which may only be used for their intended purpose ${ }^{12}$. In similar fashion, there is another Duma initiative to pay off the mortgage loans of young families at the expense of the state, if such families have children. "And the birth of each subsequent child will further reduce the payment"13. Such initiatives can contribute not only to solving demographic problems but also to territorial development.

\section{Conclusions}

An analysis of the population movement of municipalities shows that in regards to Russia the assumptions adopted in the theory of central places are only partially true. The above examples allow us to say that this theory works in the main strip of the settlement from Belgorod and Sochi to Krasnoyarsk. At the same time, it is poorly suited to the situation in areas where there are virtually no settlements capable of performing the function of central places.

The main hypothesis of population growth in some municipalities and its decline in others is based on the uneven distribution of central places in the settlement system that ensure the availability of goods and services for the entire population that gravitates towards them.

In general, the growth trend of a central high-level hierarchy dominates today. The population trends primarily towards the agglomerations. Here, it can count on raising the standard of living, which is connected with the availability of jobs, goods and services. This circumstance is due to the fact that the municipal system in Russia inherits all the features of the pre-existing administrativeterritorial division. Therefore, it weakly meets the requirements of the location of production, meeting the needs of the population in goods and services, as well as the whole complex of market relations.

In recent years, one of the main problems of municipal development has been the transformation of municipal districts into city districts. There are two possibilities to change this trend. One is to stop such transformation. Because it destroys the foundations of Local Self-Government. Another possibility is to amend the 131-FZ, which allows municipal settlements to be preserved in city districts. Of course, this option is more complicated and takes time. The main problem here is that municipal settlements are an important part of Local Self-Government. Without them, it becomes meaningless. In ac-

\footnotetext{
${ }^{12}$ Neratov D. Rossianam mogut razdat zemli besplatno [Russians will be given the land for free]. Available at: http://www.utro.ru/main/ (accessed: 20 April, 2017).

${ }^{13}$ Rossianam predlozhili proshchenie dolga po ipoteke za rozhdenie detei [Russians were offered a forgiveness of the mortgage debt for the birth of children]. Rossiiskaia gazeta, 27 March, 2016. Available at: http://lenta.ru/ news/2016/03/27/need_more_babies/ (accessed: 25 April, 2017).
} 
cordance with the law, the boundaries of the settlement - the primary unit of Local Self-Government - are set to take into account pedestrian accessibility during the working day, there and back, for residents of all the populated items included in the composition of the settlement ${ }^{14}$. There is an urgent need for the disaggregation of large municipal formations and an increase in the number of municipal settlements.

\section{REFERENCES}

1. Christaller, W. (1967). Central Places in Southern Germany. New York: Englewood Cliffs.

2. Granberg, A.G. (2004). Osnovy regionalnoi ekomomiki [Basics of regional economy]. Moscow: HSE.

3. Kolennikova, O.A., Patsiorkovskiy, V.V. \& Simagin, Yu.A. (2015). Osobennosti usloviy zhizni i vosproizvodstva naselenia: Munitsipalnyi razrez. (In: Narodonaselenie sovremennoii Rossii: vosproizvodstvo i razvitie) [Population of Modern Russia: Reproduction and Development (In: Features of Living Conditions and Population Reproduction: The Municipal Section)]. Moscow: “Econ-Inform”, pp. 192-215.

4. Losch A. (2007). Prostranstvennaia organizatsia khoziaistva [Spatial Organization of the Economy]. Moscow: Nauka.

5. Patsiorkovskiy, V.V. (2010). Selsko-gorodskaia Rossia [Rural-Urbun Russia]. Moscow: ISESP RAS.

6. Morozova, A. (2014). "Bol'shomu Belgorodu" - bol'shoe plavanie [Great Belgorod Requires Great Sailing]. Belgorodskaia pravda, 05 March., no 032, p. 2.

7. Wirth, L. (2005). Urbanizatsia kak obraz zhizni. (In: Izbrannye raboty po sotsiologii) [Urbanization as a way of life. (In: Selected Works on Sociology)]. Moscow: INION RAS (in Russian).

\footnotetext{
${ }^{14}$ State Duma of the Russian Federation. Federal Law N131-FZ of 06 October, 2003. On General Principles of the Organization of Local Self-Government in the Russian Federation. Art. 11, par. 1, p. 11. Available at: http://www.consultant.ru/document/cons_doc_LAW_148889/ (accessed: 25 March, 2017).

See also: Kolennikova, Patsiorkovskiy \& Simagin, 2015, p. 195.
} 